\title{
REDUCTION OF SPECIFIC CONDUCTIVITY IN COAL MINE EFFLUENT USING MEMBRANE TECHNOLOGY ${ }^{1}$
}

\author{
Zachary E. Kemak ${ }^{2}$, Gregory D. Boardman, Jeffrey Parks, and Catherine Grey
}

\begin{abstract}
In recent years, researchers have reported a correlation between specific conductivity (SC) and total dissolved solids (TDS) and the health of aquatic organisms in receiving streams near coal mine valley-fill structures. Due to the potential for regulatory limits on SC and TDS, coal mining operations have begun to explore treatment technologies that could be used to reduce the levels of SC and TDS in receiving streams. Nanofiltration was evaluated based on its ability to reduce SC and meet a proposed limit of $500 \mu \mathrm{S} / \mathrm{cm}$ for mine water samples with moderate and high levels of SC from southwestern VA. Three nanofilters (NF270, DK, NFX) were tested without any pretreatment in the first phase of this project. The DK and NFX nanofilters were able to meet this SC limit for both mine waters tested with an average reduction of 84 percent for both mine waters tested. The NF270 nanofilters tested provided for an average SC reduction of 69 and 59 percent for the moderate and high SC mine waters tested, respectively. Performance in terms of SC reduction declined as ion concentrations increased in the influent tested. In the second phase of this project, microfiltration and simulated-sand filtration were introduced as a pretreatment stage in order to determine if $\mathrm{SC}$ reduction could be enhanced. Neither of the pretreatment options improved the SC reductions accomplished by nanofiltration.
\end{abstract}

Additional Key Words: microfiltration; nanofiltration; specific conductance; sulfate; total dissolved solids; ultrafiltration; valley-fill.

${ }^{1}$ This paper was submitted for consideration in JASMR as a Case Study and was not presented at one of the ASMR annual conferences.

${ }^{2}$ Zachary E. Kemak is a master's degree recipient, Gregory D. Boardman is a Professor Emeritus, Jeffrey Parks is a Research Scientist, and Catherine Grey is a master's degree recipient, Civil and Environmental Engineering Department, Virginia Tech, Blacksburg, VA 24061.

DOI: http://dx.doi.org/10.21000/JASMR18030001 


\section{$\underline{\text { Introduction }}$}

Coal mining operations have traditionally only been regulated for the following water quality parameters under the Surface Mining Control and Reclamation Act (SMCRA) and the Clean Water Act (CWA): pH, Fe, and total suspended solids (TSS). In recent years, the US Environmental Protection Agency (EPA) has recommended a regulatory effluent limit on specific conductance (SC) of $500 \mu \mathrm{S} / \mathrm{cm}$ based on a study that examined the correlation between SC and aquatic health in mine impaired waters (Cormier et al., 2011). Other investigators have found that elevated SC levels can negatively impact benthic macroinvertebrates which are typically used as aquatic health indicators (Pond et al., 2008; Boehme, 2013). In particular, elevated sulfate $\left(\mathrm{SO}_{4}{ }^{2-}\right)$ concentrations in receiving streams have been identified to have detrimental effects on aquatic species (Timpano et al., 2010). Thus far, no SC limit has been established, but there is concern in the coal mining industry that an effluent regulation could be on the horizon (Daniels et al., 2016).

Both SC and total dissolved solids (TDS) are measures of the ionic makeup of a solution. Common ions that contribute to SC and TDS in mining waters include the following: sulfate $\left(\mathrm{SO}_{4}{ }^{2-}\right)$, calcium $\left(\mathrm{Ca}^{2+}\right)$, magnesium $\left(\mathrm{Mg}^{2+}\right)$, sodium $\left(\mathrm{Na}^{+}\right)$, potassium $\left(\mathrm{K}^{+}\right)$, and bicarbonate $\left(\mathrm{HCO}_{3}{ }^{-}\right)($Orndorff et al., 2010). Sulfate is the most common ion in solution of coal mine waters (Merovich et al., 2007). TDS can be calculated from the SC value based on a determined ratio, which can range from 0.5 to 1.0 (Oram, 2014). In order to determine this relationship, TDS must be quantified empirically for a test sample with a known SC value.

Traditionally, mining operations have utilized active treatment technologies that employ chemical addition in order to precipitate metals and raise $\mathrm{pH}$. Due to prohibitive costs related to active chemical addition systems, passive systems are becoming increasingly popular as a treatment method of mining impaired waters (Gusek and Conroy, 2007; Ziemkiewicz et al., 2003). Decision making models have been developed in order to select the passive treatment technology best suited to treat a site based on its water quality characteristics (Skousen et al., 2016). The water quality parameters typically targeted by passive treatment technologies include $\mathrm{pH}$, dissolved oxygen (DO), $\mathrm{Fe}^{+3}$. and $\mathrm{Al}^{+3}$. Given that the primary contributors to SC and TDS are diminished greatly by passive 
treatment, further investigation is required to determine suitable technologies to combat elevated SC and TDS.

Membrane technologies are increasingly being considered as possible treatment options for mining operations despite not being a truly passive treatment technology. The most common membrane technologies from smallest pore size to largest pore size are: reverse osmosis (RO), nanofiltration, ultrafiltration, and microfiltration. Microfiltration and ultrafiltration are typically used as pretreatment option for removing larger particles that could negatively impact downstream treatment processes (Awadalla and Kumar, 1994). These membranes are able to remove the following: bacteria, viruses, colloids, and some dissolved organics (Edzwald, 2011). RO has been proven to be effective in removing dissolved ions, but was not considered in this study due to the high operational costs associated with generating the pressures required; pressures as high as 1,200 psi (Edzwald, 2011).

Like RO, nanofiltration is a membrane technology that is able to remove certain dissolved ions (Awadalla and Kumar, 1994). When compared to RO, nanofiltration is able to remove dissolved ions at much lower operating pressures, which decreases a system's operating costs (Pinto et al., 2016). Nanofiltration systems are also able to operate at higher fluxes than RO systems (Diawara, 2008). One of the major concerns with membrane technologies is fouling. Scaling, a form of fouling, occurs when solids build up on the membrane surface and block pores, thus negatively impacting system performance. The type of residual formed on the membrane surface will vary depending on the influent water quality. Due to decreased treatment efficiency over time, scaling can lead to system damage and may require maintenance that would increase costs for the system (Visser et al., 2001). Another concern with nanofiltration is that the decrease in ions within a sample varies depending on the complexity of the sample (Bolisetty and Mezzenga, 2016), which is a potential performance issue when dealing with complex mine waters.

Nanofiltration has proven to be a viable option for the decrease in ions that are common in the coal mining impaired waters of southwestern VA. Several authors have applied nanofiltration to treat AMD from various types of mining operations (Al-Zoubi et al., 2010; Košutić et al., 2004; Ricci et al., 2015; Rieger et al. 2009; Sierra et al., 2013; Visser et al. 
2001). Excluding the study by Visser et al. (2001), where $\mathrm{SO}_{4}{ }^{2-}$ concentrations were low, nanofiltration achieved at least an 88 percent $\mathrm{SO}_{4}{ }^{2-}$ reduction in each of the other studies cited. The remaining major ions found in coal mine waters of southwestern VA were effectively reduced, as well.

The goal of this study was to test the feasibility of using various nanofiltration membranes to reduce SC and TDS levels in coal mining waters that are characteristic of southwestern VA. As a means of evaluating each trial, the resulting SC value after each treatment was compared to the proposed upper limit of $500 \mu \mathrm{S} / \mathrm{cm}$, as recommended by Cormier et al. (2011). The ionic makeup of the filtrate from each treatment was compared to that of the source water in order to understand the removal of each ion. Microfiltration and simulated-sand filtration pretreatment stages were also tested to determine whether or not they would improve subsequent treatment by nanofiltration.

\section{Methods}

Samples were collected from two, coal mine impaired streams located in southwestern VA. The two selected streams emanated from active, valley-fill coal mines. These streams were selected because they were known to have different levels of SC; this would allow for the testing of water samples with moderate and high levels of SC. The Office Fill (OF) samples were collected in a stream originating from a conventional, valley-fill structure. The Barton Hollow (BH) samples were collected from a valley-fill structure that utilizes an experimental system designed to lower SC levels. The collection of samples for each site was completed on separate days during the summer of 2016.

A stirred-cell system, Sterlitech HP4750, was used to conduct the membrane tests. This apparatus has a dead-end configuration that utilizes direct pressure to force the influent water sample through the system (Fig. 1). The stirred-cell system can hold a maximum of $300 \mathrm{~mL}$ of sample. Compressed nitrogen gas was used as the pressure source. A graduated cylinder was used to capture the filtered water sample and to monitor the progress of the filtration process.

For this study, multiple operating conditions were tested in order to identify the best treatment procedure. Initially, the mine water samples were tested using each type of nanofiltration membrane without a pretreatment stage. The characteristics of the three 
nanofiltration membrane tested in this phase of the study are given in Table 1. In the second phase of testing, a pretreatment stage was incorporated prior to nanofiltration testing. Two pretreatment methods were examined: microfiltration and simulated sand filtration. For microfiltration, a TriSep TM10 microfiltration membrane was used to filter the mine water samples. In order to simulate sand filtration, a Whatman GF/B filter $(1.0 \mu \mathrm{m})$ was used to filter each of the mine water samples (Edzwald, 2011). Once a prefiltered sample was obtained for each water source, tests were performed using the NFX nanofiltration membranes. The NFX nanofiltration membrane was selected based on its promising results during the first phase of testing of the $\mathrm{BH}$ samples. The SC values measured after nanofiltration were statistically analyzed using Tukey's multiple comparison test in order determine if the SC values differed for each nanofilter tested. This statistical analysis was conducted using R statistical programming.

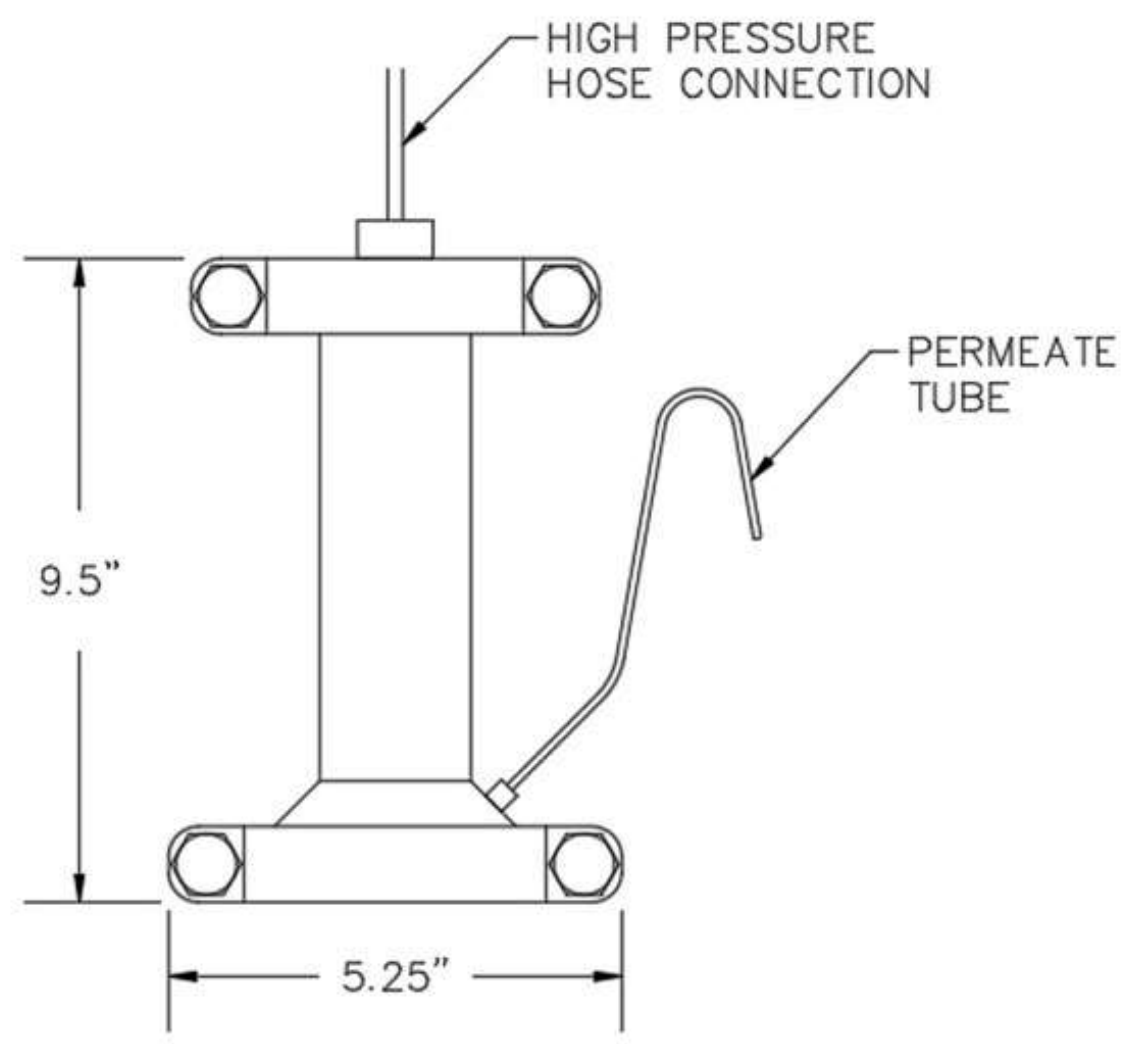

Figure 1. Basic drawing of the Sterlitech HP4750 Stirred Cell membrane apparatus. 
Journal American Society of Mining and Reclamation, 2018 Vol.7, No.3

Table 1. Summary of Nanofiltration Membrane Characteristics (Adapted from Sterlitech, 2016).

\begin{tabular}{cccc}
\hline Filter & NF270 & DK & NFX \\
\hline Manufacturer & Dow Filmtec & GE Osmonics & Synder Filtration \\
Polymer & Polyamide- & Thin Film & Polyamide-TFC \\
& TFC & & \\
MWCO (daltons) & $200-400$ & $150-300$ & $150-300$ \\
pH & $2-11$ & $2-10$ & $3-10.5$ \\
Flux (GFP/psi) & $(72-98) / 130$ & $22 / 100$ & $(20-25) / 110$ \\
Flux (GFP/bar) & $(72-98) / 8.96$ & $22 / 6.89$ & $(20-25) / 7.58$ \\
\hline
\end{tabular}

*MWCO - Molecular Weight Cut-Off

For a given test, the selected membrane was placed in the filter support. Once in place, the apparatus was assembled as specified by the manufacturer. Prior to testing the water sample, $100 \mathrm{~mL}$ of nanopure water was added to the assembly to allow for conditioning of the membrane. During this conditioning step, the same operating pressure to be used during the filtration of the water sample was used for consistency. The conditioning step was continued until the water flux being monitored reached a steady-state. During the operation of the membrane apparatus, the water flux was monitored by tracking the volume of collected filtrate at specified time intervals until the entire system was completely emptied. The water flux was calculated using Equation 1:

$$
J=Q / A_{M}
$$

In order to complete this calculation, a timer was used to monitor the filtrate collected at specified time intervals. Using these data, the flow-rate (Q) of the system was determined, and the water flux was then calculated by dividing $Q$ by the membrane's surface area $\left(A_{M}\right)$.

After membrane conditioning was completed, the apparatus was disassembled and 100 $\mathrm{mL}$ of the desired mine water sample was added. Once reassembled, the apparatus was connected to the pressure source and the pressure regulator was set to the desired pressure. Eight bar (116 psi) was selected as the operating pressure for each trial based on the manufacturer's recommendation for optimal operational flux and for consistency in working with each filter. Once the pressure valve was opened and the first droplet of filtrate fell into the graduated cylinder, a timer was started. Every five minutes, the amount of filtrate present in the graduated cylinder was recorded in order to calculate the water 
flux. During the operation of the apparatus, a magnetic stirrer (Benchmark Magnetic Stirrer) was set to a mid-range stirring rate. For each specific membrane, tests were performed at least in triplicate (in some cases more replicates were performed). Between individual tests, the membranes were gently rinsed and soaked with nanopure water for at least 10 minutes.

The SC of the filtrate was measured using an Omega CDH-SD1 conductivity meter. SC to TDS ratios were determined by measuring the TDS of samples at the following SC ranges: $0-1,000 \mu \mathrm{S} / \mathrm{cm}, 1,000-2,000 \mu \mathrm{S} / \mathrm{cm}$, and greater than 2,000 $\mu \mathrm{S} / \mathrm{cm}$. TDS was determined in accordance with Standard Methods 2540-C for five replicates from each of the specified SC ranges (Rice et al., 2012). This testing yielded the following SC to TDS ratios for the $0-1,000 \mu \mathrm{S} / \mathrm{cm}, 1,000-2,000 \mu \mathrm{S} / \mathrm{cm}$, and greater than 2,000 $\mu \mathrm{S} / \mathrm{cm}$ ranges of $0.64,0.83$, and 0.95 , respectively. Inductively coupled plasma - mass spectrometry (ICPMS) was used to measure the concentrations of cations and sulfate present in the source water and filtrate. Alkalinity was measured via the titration methodology using $0.02 \mathrm{~N}$ sulfuric acid as recommended by Standard Methods 2320-B (Rice et al., 2012). The pH of the filtrate samples was measured using a pH meter (Oakton acorn series, pH 6 meter). Turbidity was measured using a turbidimeter (Orbeco-Hellige digital direct-reading turbidimeter). All meters used in this study were calibrated weekly prior to testing.

A build-up of residual solids was expected to develop on the surface of the membrane during testing. Unrinsed NF270 filters after the treatment of BH water samples were submerged in $100 \mathrm{~mL}$ of nanopure water and agitated to get a better understanding of the residual solids that developed on the surface of nanofilters after operation. The samples collected were then vigorously shaken in order to promote the dissolving of the solids in solution. These samples were then analyzed by means of ICP-MS to better understand the cationic makeup of each sample. The dry weight of the residual solids in each sample was quantified by drying $10 \mathrm{~mL}$ of each sample at a temperature range of $103^{\circ} \mathrm{C}$ to $105^{\circ} \mathrm{C}$. The results of ICP-MS analysis were reported on a unit weight basis.

\section{$\underline{\text { Results and Discussion }}$}

Characteristics of the mine impaired waters examined in this study are provided in Table 2. Initially, each type of nanofilter was individually tested to treat samples from 
both water sources. In terms of SC reduction, Fig. 2 and 3 display the effluent SC levels achieved by each individual membrane for both influent water samples. For the BH water samples, both of the low-flux nanofiltration membranes (NFX and DK) were able achieve SC reductions below the proposed $500 \mu \mathrm{S} / \mathrm{cm}$ limit. The NFX and DK nanofilters were able to achieve an average of 82 and 86 percent SC reduction, respectively. The NF270 nanofilter provided the least amount of SC reduction (69 percent) of the three nanofiltration membranes being tested. The NF270 nanofilter also had the highest variability in terms of SC reduction with a standard deviation of $155 \mu \mathrm{S} / \mathrm{cm}$, while NFX and DK had standard deviations below $50 \mu \mathrm{S} / \mathrm{cm}$. For the OF water samples, similar trends in terms of SC reduction were found. Both NFX and DK reduced SC on average of 83 and 85 percent, respectively, and were able achieve average SC levels below $500 \mu \mathrm{S} / \mathrm{cm}$. When compared to the $\mathrm{BH}$ samples, the $\mathrm{OF}$ nanofilter results tended to have more variation in terms of standard deviation. The increased variation experienced during the testing of the OF samples is believed to be related to the higher concentrations of ionic constituents compared to those found in the $\mathrm{BH}$ samples. In this respect, DK experienced the lowest standard deviation at $77 \mu \mathrm{S} / \mathrm{cm}$, while NF270 had a standard deviation of $246 \mu \mathrm{S} / \mathrm{cm}$.

Table 2. Summary of Water Quality Characteristics.

\begin{tabular}{|c|c|c|}
\hline Characteristics & Barton Hollow $(\mathrm{BH})$ & Office Fill (OF) \\
\hline $\mathrm{SC}(\mu \mathrm{S} / \mathrm{cm})$ & 1,534 & 2,505 \\
\hline TDS (mg/L) & 1,273 & 2,380 \\
\hline $\mathrm{pH}$ & 7.53 & 7.62 \\
\hline Alkalinity $\left(\mathrm{mg} / \mathrm{L}\right.$ as $\left.\mathrm{CaCO}_{3}\right)$ & 100 & 198 \\
\hline Turbidity (NTU) & 7.19 & 12.90 \\
\hline $\mathrm{SO}_{4}{ }^{2-}(\mathrm{mg} / \mathrm{L})$ & 776 & 1,380 \\
\hline $\mathrm{Ca}^{2+}(\mathrm{mg} / \mathrm{L})$ & 181 & 346 \\
\hline $\mathrm{Mg}^{2+}(\mathrm{mg} / \mathrm{L})$ & 93.6 & 247 \\
\hline $\mathrm{Na}^{+}(\mathrm{mg} / \mathrm{L})$ & 22.8 & 36.0 \\
\hline $\mathrm{K}^{+}(\mathrm{mg} / \mathrm{L})$ & 7.7 & 10.5 \\
\hline
\end{tabular}


Journal American Society of Mining and Reclamation, 2018 Vol.7, No.3

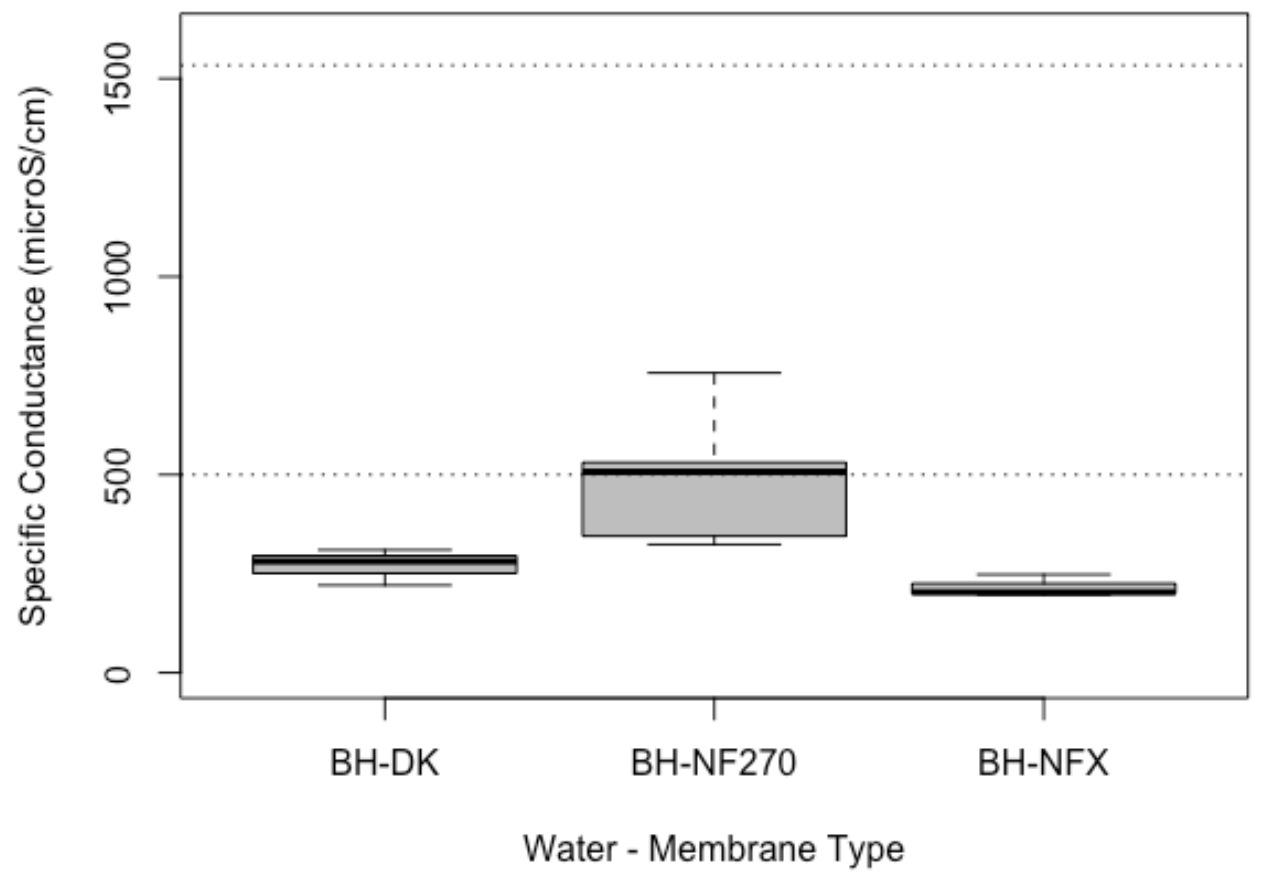

Figure 2. Filtrate SC levels after nanofiltration of $\mathrm{BH}$ water samples when compared to influent and targetted effluent SC levels.

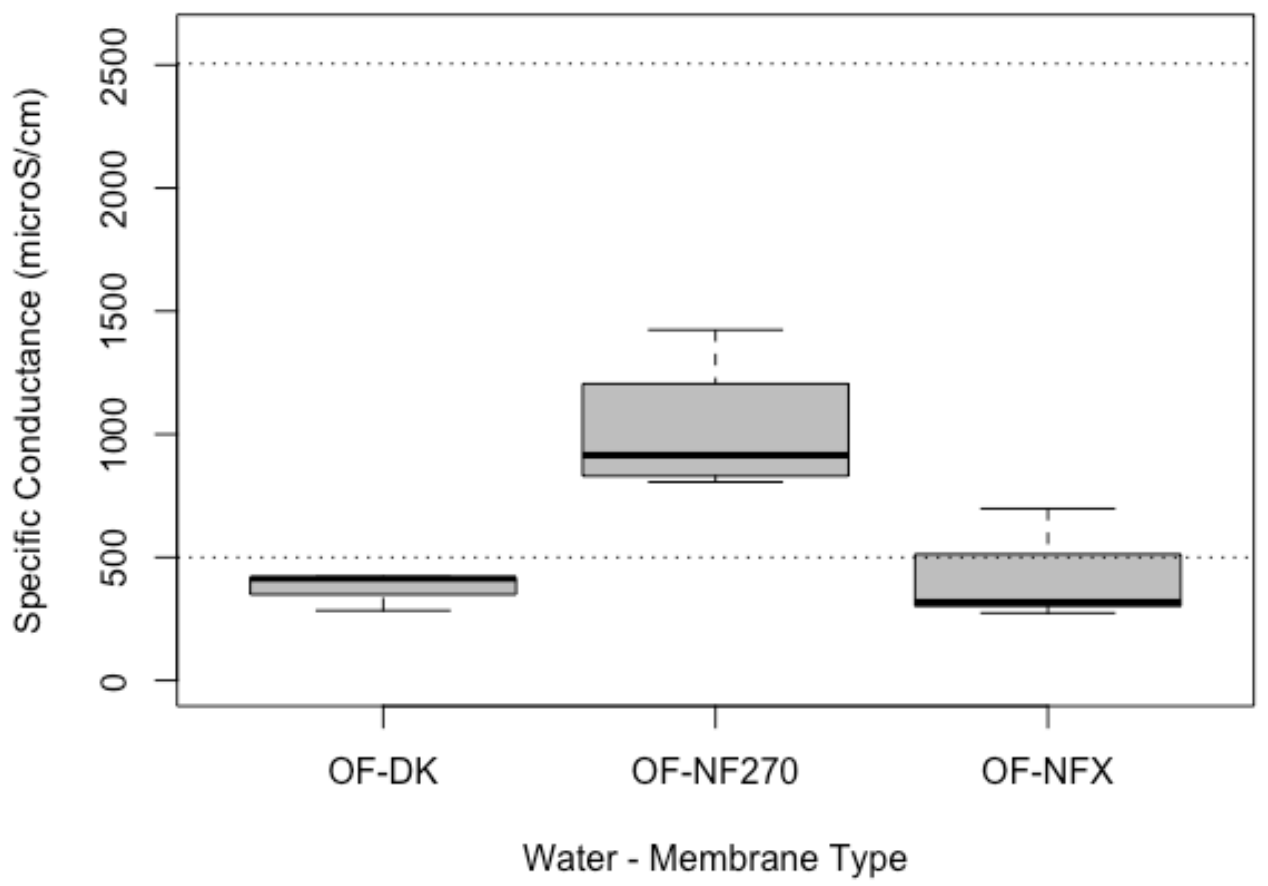

Figure 3. Filtrate SC levels after nanofiltration for OF water samples when compared to influent and targeted effluent SC levels.

In order to monitor membrane fouling, water flux was monitored during each membrane test. The water flux for each membrane monitored over time can be seen in 
Fig. 4. The water flux results followed similar trends to previous studies (Al-Zoubi et al., 2010). For all nanofilters tested, the water flux measured decreases during the performance of the membrane apparatus. This is most likely due to the accumulation of solids on and within the membrane, which would impact the flowrate of the system and thus the calculated flux. Table 3 provides the average concentrations of ions measured in the filtrates of tests with each nanofilter. Each of the nanofilters performed well in terms of decrease in $\mathrm{SO}_{4}{ }^{2-}$ with the minimum decrease for all water samples at $77 \%$. Average decrease in $\mathrm{SO}_{4}{ }^{2-}$ for the testing conducted on $\mathrm{BH}$ water samples was 84,94 , and $98 \%$ for NF270, DK, and NFX, respectively. Average decreases in $\mathrm{SO}_{4}{ }^{2-}$ for the testing conducted on OF water samples were 77, 96, and 94 percent for NF270, DK, and NFX, respectively. The divalent cations examined in this study, $\mathrm{Ca}^{2+}$ and $\mathrm{Mg}^{2+}$, experienced similar average decreases to $\mathrm{SO}_{4}{ }^{2-}$ which ranged from 71 to 96 percent. Of the cations and anions examined in this study, $\mathrm{Na}^{+}$and $\mathrm{K}^{+}$had the lowest average decreases for both mine waters tested. For $\mathrm{BH}$ test samples, the $\mathrm{Na}^{+}$and $\mathrm{K}^{+}$maximum average decreases among the three nanofilters tested were 40 and 45 percent, respectively. For OF test samples, the $\mathrm{Na}^{+}$and $\mathrm{K}^{+}$maximum average decreases among the three nanofilters tested were 37 and 45 percent, respectively. Of the three nanofilters tested, the NF270 had the highest decreases in $\mathrm{Na}^{+}$ and $\mathrm{K}^{+}$.

The decrease in $\mathrm{SO}_{4}{ }^{2-}$ achieved by NF270 nanofiltration treatment can be compared to those found by Košutić et al. (2004). Testing from Košutić et al. (2004) had a $\mathrm{SO}_{4}{ }^{2-}$ decrease of 95 percent. This $\mathrm{SO}_{4}{ }^{2-}$ decrease was greater than that reached by using the NF270 to treat both $\mathrm{BH}$ and OF water samples. The results from DK testing can be compared to those found by Al-Zoubi et al. (2010). Al-Zoubi et al. (2010) was able to achieve $\mathrm{SO}_{4}{ }^{2-}, \mathrm{Mg}^{2+}, \mathrm{Ca}^{2+}$, and $\mathrm{Na}^{+}$decreases of $98,99,99$, and $90 \%$, respectively. These decreases were comparable to those achieved in this study, except for that found for $\mathrm{Na}^{+}$ which was only able to decrease by 15 and 40 percent for $\mathrm{BH}$ and $\mathrm{OF}$ water samples, respectively. 
Journal American Society of Mining and Reclamation, 2018 Vol.7, No.3

A

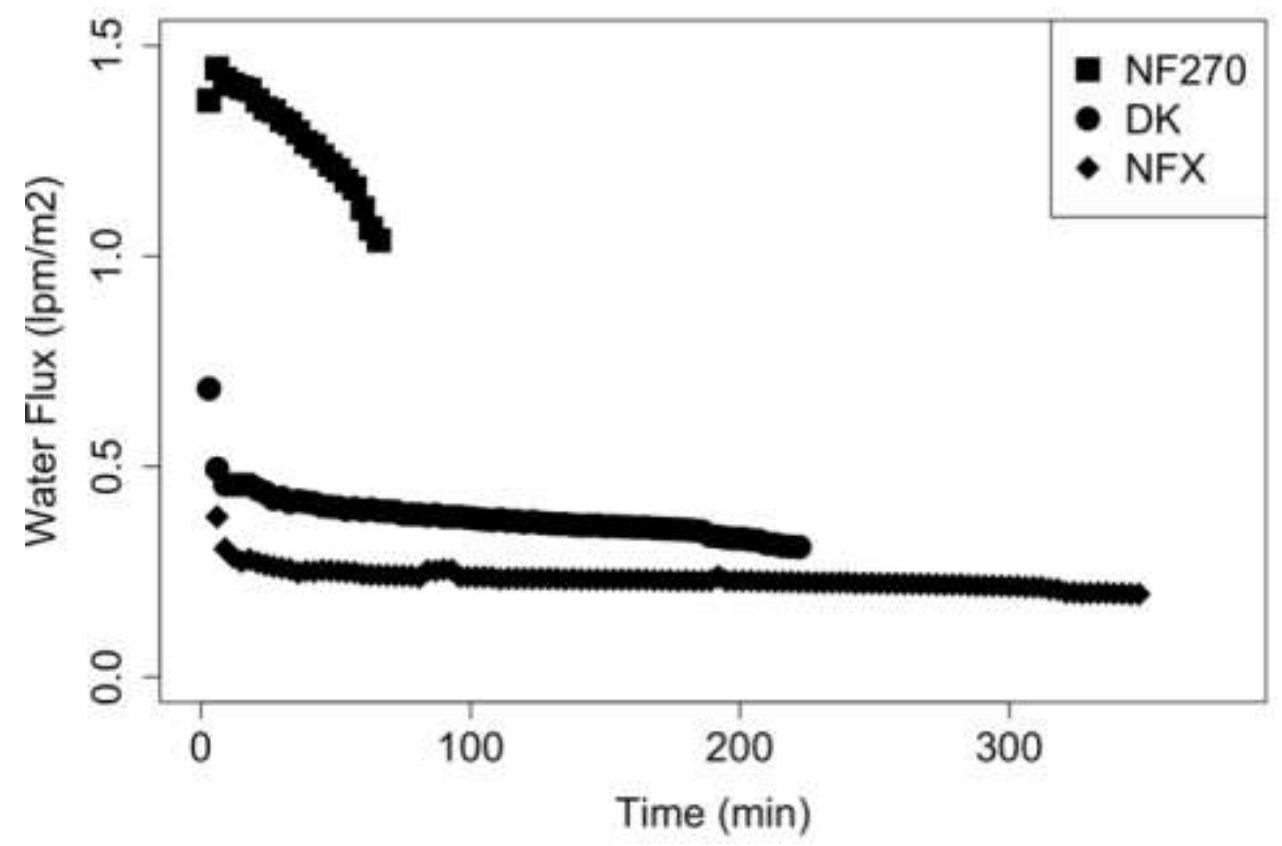

B

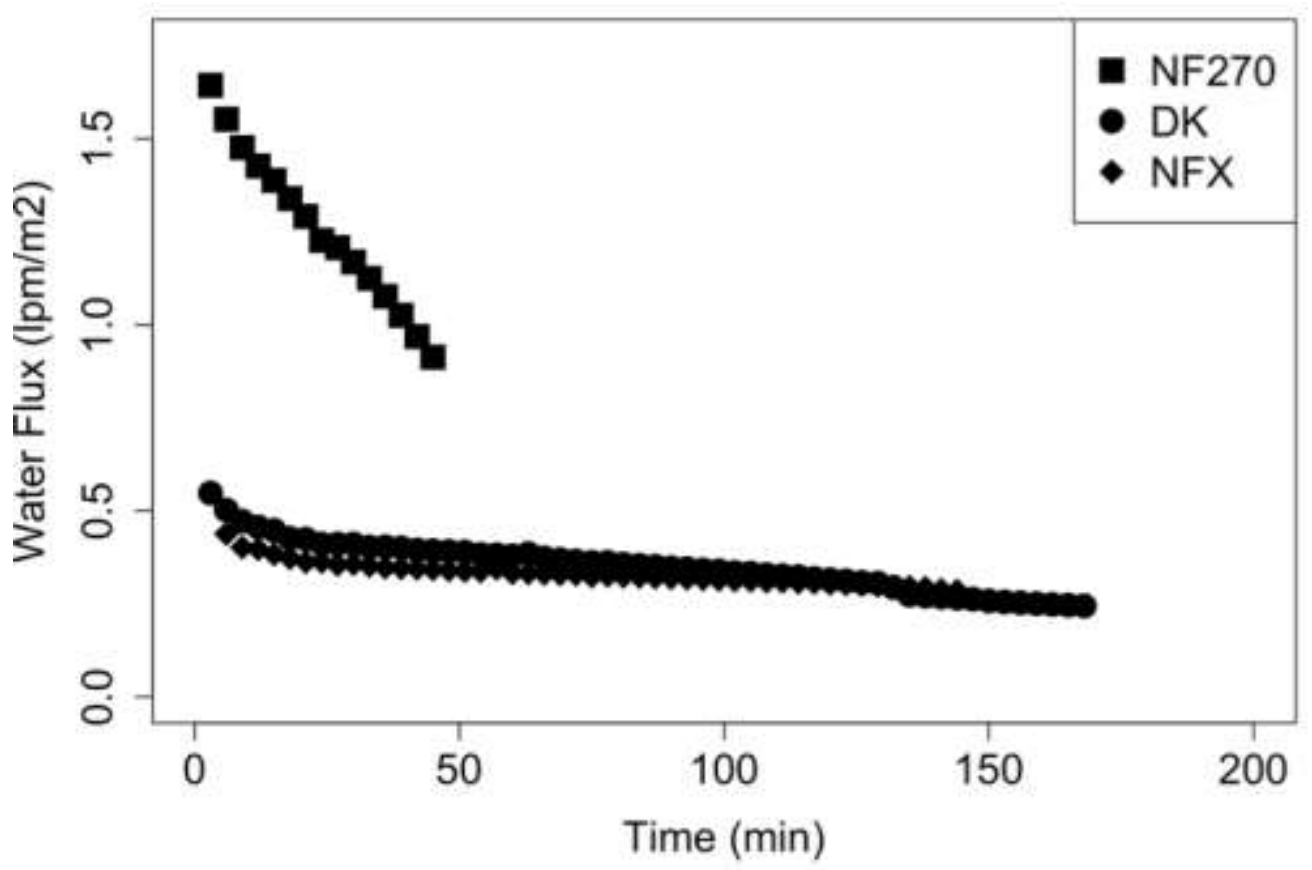

Figure 4. Water flux over time for (A) $\mathrm{BH}$ and (B) $\mathrm{OF}$ tests measured in (liter-perminute)/(meter squared).

Fig. 5 shows how the residuals were typically deposited on the membrane apparatus and the membrane filter at the end of an experiment. The residuals deposited on the membrane surface coated the part of the apparatus closest to the membrane. This residual remained on the surface of the membrane apparatus unless it was vigorously scoured. Very 
little residual on the membrane apparatus was able to be removed. As mentioned earlier, multiple studies identified gypsum as a common scalant in these systems (Al-Zoubi et al., 2010; Rieger et al., 2009). A significant amount of the residual from the membrane apparatus was unable to be obtained for further analysis in order to chemically identify the substance. Most of the solids on the surface of the membrane were easily removed by rinsing the membrane surface with water. The ions found in the residuals tested using ICPMS can be found in Table 4. Based on the high $\mathrm{SO}_{4}{ }^{2-}$ and $\mathrm{Ca}^{2+}$ decreases achieved by the NF270 nanofilter after treatment of BH water samples and the fact that these two ions have the highest concentrations in the influent, it makes sense that these ions would be accumulated on the surface of the membrane in the greatest concentrations.

A

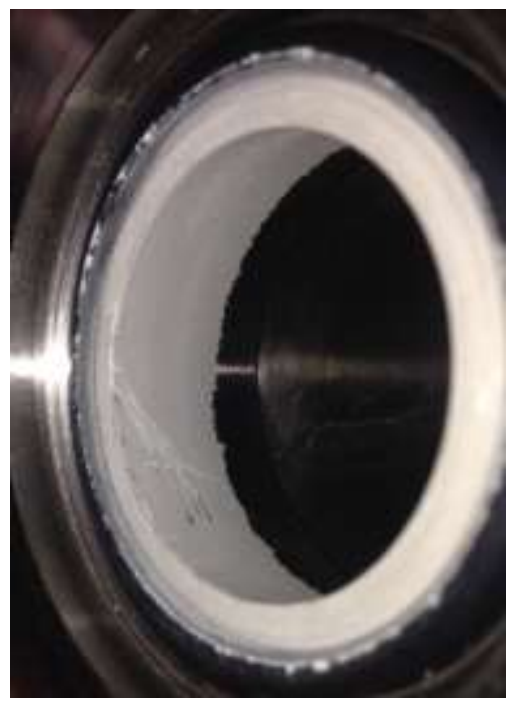

B

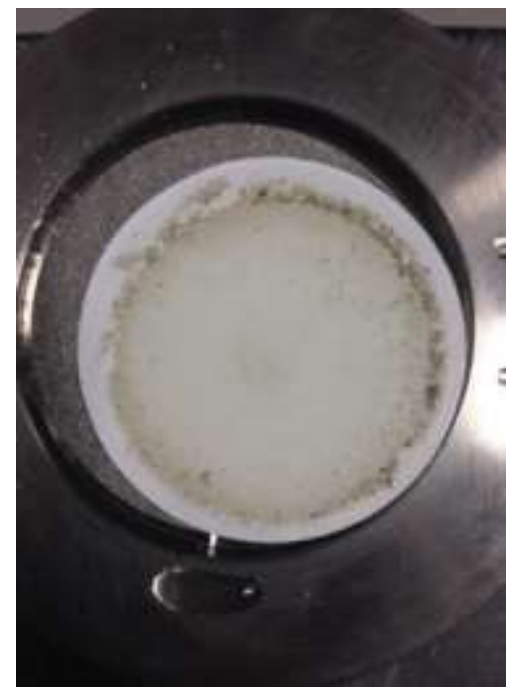

Figure 5. (A) Solids build up membrane apparatus and (B) solids accumulation on membrane surface.

Table 3. Summary of phase I filtrate water quality characteristics.

\begin{tabular}{cccccccccccc}
\hline $\begin{array}{c}\text { Water } \\
\text { Source }\end{array}$ & Nanofilter & $\begin{array}{c}\text { No. of } \\
\text { Rep. } \\
(\mathrm{n})\end{array}$ & $\begin{array}{c}\mathrm{SC} \\
(\mu \mathrm{S} / \mathrm{cm})\end{array}$ & $\begin{array}{c}\mathrm{TDS} \\
(\mathrm{mg} / \mathrm{L})\end{array}$ & $\mathrm{pH}$ & $\begin{array}{c}\text { Alkalinity } \\
(\mathrm{mg} / \mathrm{L} \text { as } \\
\left.\mathrm{CaCO}_{3}\right)\end{array}$ & $\begin{array}{c}\mathrm{SO}_{4}^{2-} \\
(\mathrm{mg} / \mathrm{L})\end{array}$ & $\begin{array}{c}\mathrm{Ca}^{2+} \\
(\mathrm{mg} / \mathrm{L})\end{array}$ & $\begin{array}{c}\mathrm{Mg}^{2+} \\
(\mathrm{mg} / \mathrm{L})\end{array}$ & $\begin{array}{c}\mathrm{Na}^{+} \\
(\mathrm{mg} / \mathrm{L})\end{array}$ & $\begin{array}{c}\mathrm{K}^{+} \\
(\mathrm{mg} / \mathrm{L})\end{array}$ \\
\hline BH & $\mathrm{NF} 270$ & 7 & 477 & 324 & 7.90 & 79 & 122 & 37 & 25 & 14 & 4 \\
BH & $\mathrm{DK}$ & 3 & 271 & 184 & 7.63 & 57 & 43 & 14 & 11 & 19 & 8 \\
BH & NFX & 3 & 216 & 147 & 7.82 & 65 & 13 & 17 & 6 & 16 & 5 \\
OF & NF270 & 7 & 1,031 & 783 & 8.14 & 197 & 311 & 78 & 71 & 22 & 6 \\
OF & DK & 3 & 373 & 253 & 7.82 & 92 & 50 & 13 & 17 & 26 & 7 \\
OF & NFX & 5 & 421 & 286 & 7.86 & 91 & 78 & 26 & 16 & 24 & 7 \\
\hline
\end{tabular}


Journal American Society of Mining and Reclamation, 2018 Vol.7, No.3

Table 4. ICP-MS analysis of accumulated solids on DK membrane.

\begin{tabular}{cccccc}
\hline Sample & $\begin{array}{c}\mathrm{SO}_{4}{ }^{2-} \\
(\mathrm{mg} / \mathrm{mg})\end{array}$ & $\begin{array}{c}\mathrm{Ca}^{2+} \\
(\mathrm{mg} / \mathrm{mg})\end{array}$ & $\begin{array}{c}\mathrm{Mg}^{2+} \\
(\mathrm{mg} / \mathrm{mg})\end{array}$ & $\begin{array}{c}\mathrm{Na}^{+} \\
(\mathrm{mg} / \mathrm{mg})\end{array}$ & $\begin{array}{c}\mathrm{K}^{+} \\
(\mathrm{mg} / \mathrm{mg})\end{array}$ \\
\hline $\mathrm{S} 1$ & 0.471 & 0.156 & 0.023 & 0.005 & 0.003 \\
$\mathrm{~S} 2$ & 2.188 & 0.621 & 0.138 & 0.015 & 0.007 \\
$\mathrm{~S} 3$ & 0.816 & 0.272 & 0.032 & 0.004 & 0.002 \\
\hline
\end{tabular}

The second phase of testing introduced one of two pretreatment options prior to direct nanofiltration testing: microfiltration (MFNF) and simulated-sand filtration (SFNF). Initially, at least $300 \mathrm{~mL}$ of water sample were filtered using each of the pretreatment methods. Both pretreatment options provided minimal SC reduction to the tested influent samples; this was to be expected based on the previously reported kinds of molecules removed by microfiltration membranes (Edzwald, 2011). Even though the influent water samples tested already had mean turbidity levels below 15 NTU, both pretreatment options were able to reduce turbidity to levels achieved by nanofiltration in the first phase of nanofiltration testing. The NFX nanofilter was selected for treatment of the pretreated samples due to its promising results in terms of $\mathrm{SC}$ reduction during the testing of $\mathrm{BH}$ samples.

Fig. 6 and 7 depict the SC levels achieved by nanofiltration after each of the prescribed pretreatment steps. For the BH samples, each of the treatments were able to reduce SC lower than the $500 \mu \mathrm{S} / \mathrm{cm}$ SC limit on average. When compared to the NFX treatment of BH water samples, only the samples microfiltered prior to nanofiltration were statistically different in terms of end SC level based on a multiple comparison test. The previously microfiltered samples had an average effluent SC level of $306 \mu \mathrm{S} / \mathrm{cm}$, which was greater than both effluent SC levels obtained by the other testing conditions. For the OF samples, each of the treatments were not statistically different from the NFX samples collected without pretreatment in terms of end SC level based on a multiple comparison statistical analysis. Each of the treatments were not able to reduce the SC of the pretreated OF samples lower than the $500 \mu \mathrm{S} / \mathrm{cm}$ SC limit on average. Table 5 contains the mean characteristics of each of the filtered samples collected during this phase of experimentation. 
Journal American Society of Mining and Reclamation, 2018 Vol.7, No.3

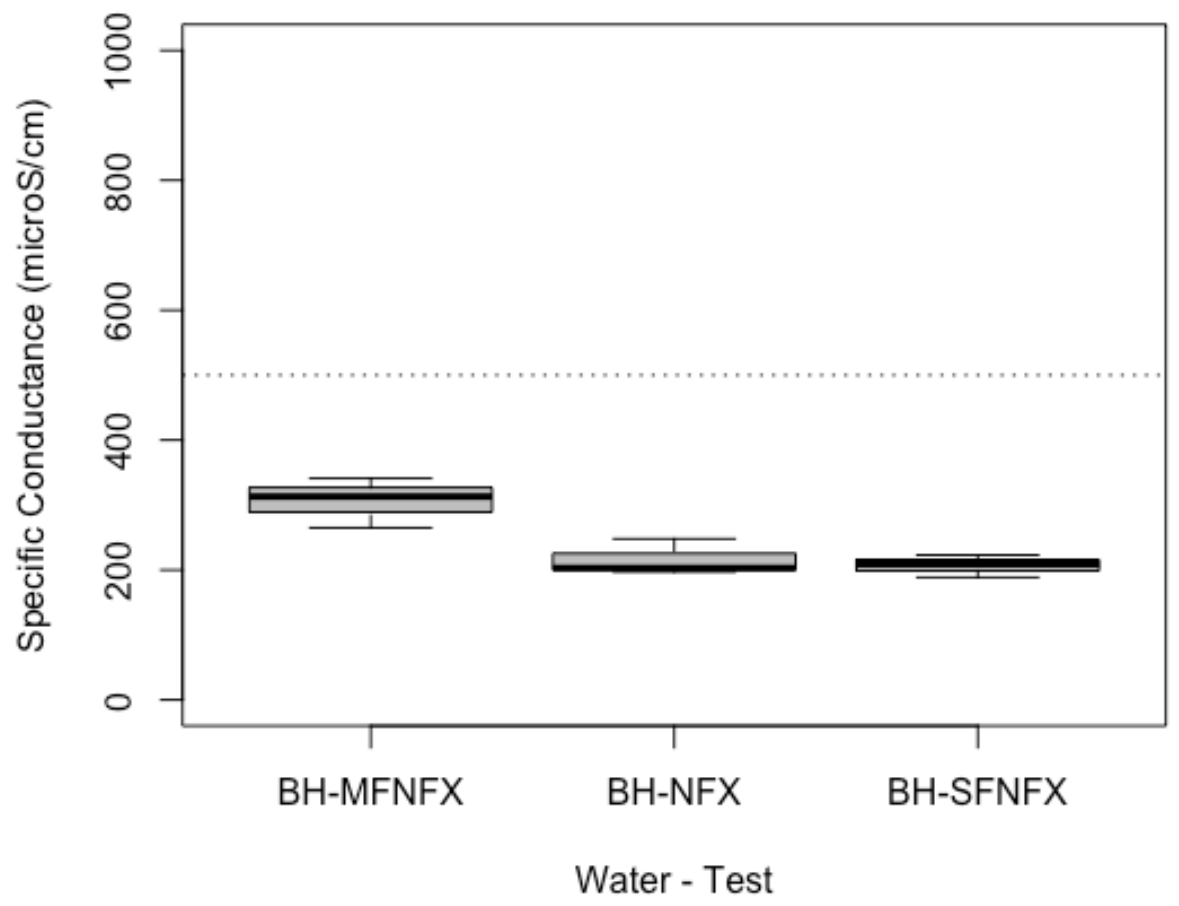

Figure 6. Nanofiltration of BH samples after pretreatment.

Table 5. Summary of phase II filtrate water quality characteristics.

\begin{tabular}{|c|c|c|c|c|c|c|c|c|c|c|}
\hline $\begin{array}{c}\text { Wate } \\
\text { r } \\
\text { Sour } \\
\text { ce }\end{array}$ & Test & $\begin{array}{c}\mathrm{SC} \\
(\mu \mathrm{S} / \mathrm{c} \\
\mathrm{m})\end{array}$ & $\begin{array}{c}\text { TDS } \\
(\mathrm{mg} / \\
\mathrm{L})\end{array}$ & $\mathrm{pH}$ & $\begin{array}{c}\text { Alkalin } \\
\text { ity } \\
(\mathrm{mg} / \mathrm{L} \\
\text { as } \\
\left.\mathrm{CaCO}_{3}\right)\end{array}$ & $\begin{array}{c}\mathrm{SO}_{4}{ }^{2-} \\
(\mathrm{mg} / \\
\mathrm{L})\end{array}$ & $\begin{array}{c}\mathrm{Ca}^{2+} \\
(\mathrm{mg} / \\
\mathrm{L})\end{array}$ & $\begin{array}{c}\mathrm{Mg}^{2+} \\
(\mathrm{mg} / \\
\mathrm{L})\end{array}$ & $\begin{array}{c}\mathrm{Na}^{+} \\
(\mathrm{mg} / \\
\mathrm{L})\end{array}$ & $\begin{array}{c}\mathrm{K}^{+} \\
(\mathrm{mg} / \\
\mathrm{L})\end{array}$ \\
\hline $\mathrm{BH}$ & $\begin{array}{c}\text { SFN } \\
\text { F }\end{array}$ & 207 & 141 & $\begin{array}{c}7.7 \\
8\end{array}$ & 56 & 18 & 12 & 5 & 15 & 5 \\
\hline $\mathrm{BH}$ & $\begin{array}{c}\mathrm{MFN} \\
\mathrm{F}\end{array}$ & 306 & 208 & $\begin{array}{c}7.8 \\
2\end{array}$ & 62 & 39 & 19 & 9 & 13 & 4 \\
\hline $\mathrm{OF}$ & $\begin{array}{c}\text { SFN } \\
\text { F }\end{array}$ & 556 & 378 & $\begin{array}{c}8.0 \\
3\end{array}$ & 112 & 112 & 33 & 27 & 23 & 6 \\
\hline $\mathrm{OF}$ & $\begin{array}{c}\mathrm{MFN} \\
\mathrm{F}\end{array}$ & 562 & 382 & $\begin{array}{c}7.9 \\
7\end{array}$ & 98 & 124 & 29 & 30 & 23 & 6 \\
\hline
\end{tabular}




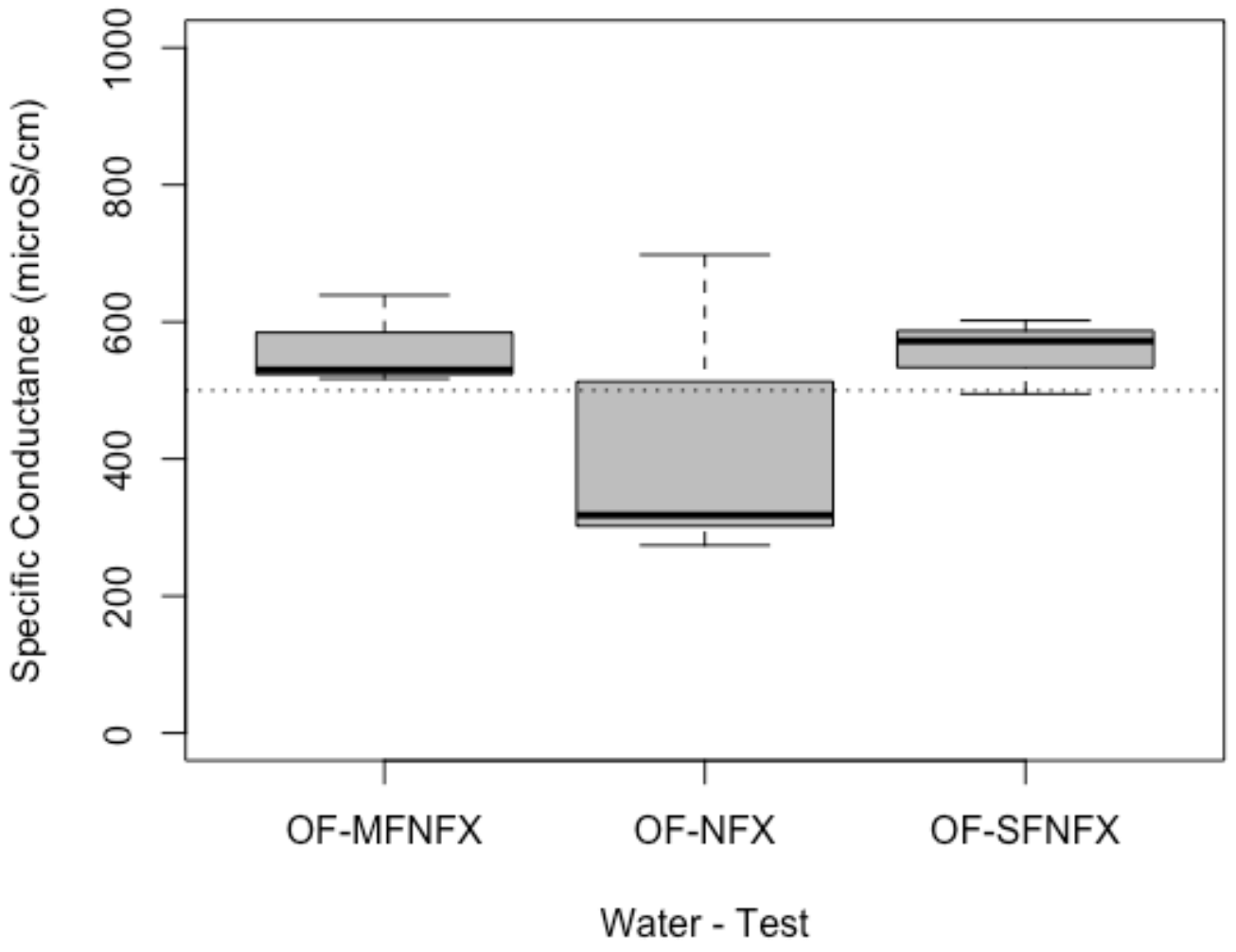

Figure 7. Nanofiltration of OF samples after pretreatment.

When compared to the effluent ion concentrations achieved by the NFX nanofilter in the first phase of this study, the ionic concentrations and associated decreases were comparable to those found when a pretreatment stage was incorporated prior to nanofiltration. For both testing conditions and water samples, the decreases in $\mathrm{SO}_{4}{ }^{2-}$ all exceeded 90 percent. Like in the first phase of experimentation, $\mathrm{Na}^{+}$and $\mathrm{K}^{+}$decreases were the lowest among the ions measured. The average decreases in $\mathrm{Na}^{+}$and $\mathrm{K}^{+}$for both testing conditions were between 30 and 40 percent.

\section{$\underline{\text { Conclusions }}$}

At the lab scale, nanofiltration was shown to be a potentially effective treatment technology for SC reduction. Of the three nanofiltration membranes tested, the low-flux nanofilters (DK and NFX) on average were able to meet the potential $500 \mu \mathrm{S} / \mathrm{cm}$ SC limit for both mine waters tested. Each of these nanofilters were able to decrease $\mathrm{SO}_{4}{ }^{2-}$ concentrations by at least 90 percent. The NF270 nanofilter experienced the greatest amount of variability of the three nanofilters tested. In general, as ion concentrations increased in the influent tested with the OF samples, variability of membrane performance 
increased. When a pretreatment stage of microfiltration or simulated-sand filtration was introduced prior to nanofiltration, increased performance in terms of SC reduction was not achieved.

Further testing will be required to determine whether nanofiltration will be a viable option in full-scale applications for treating mine impaired waters. In this respect, experimentation should be conducted with a continuous flow membrane system due to its widespread full-scale application. Testing of mine water samples from streams that are known to be more turbid than those tested in this study would allow for the identification of the optimal pretreatment stage prior to nanofiltration.

\section{Acknowledgements}

This study was sponsored by the Appalachian Research Initiative for Environmental Science (ARIES). The views, opinions, and recommendations expressed herein are solely those of the authors and do not imply any endorsement by ARIES employees, other ARIES-affiliated researchers, or industrial members. Water samples were obtained from streams emanating from coal valley-fill structures in coordination with ARIES.

\section{$\underline{\text { Literature Cited }}$}

Al-Zoubi, H., A. Rieger, P. Steinberger, W. Pelz, R. Haseneder, and G. Härtel. 2010. Nanofiltration of acid mine drainage. Desalination and Water Treatment 21: 148-161. https://doi.org/10.5004/dwt.2010.1316

Awadalla, F.T. and A. Kumar. 1994. Opportunities for Membrane Technologies in the Treatment of Mining and Mineral Process Streams and Effluents. Separation Science and Technology 29: 1231-1249. https://doi.org/10.1080/01496399408006938

Boehme, E.A. 2013. Temporal Dynamics of Benthic Macroinvertebrate Communities and Their Response to Elevated Specific Conductance in Headwater Streams of the Appalachian Coalfields. M.S. Thesis, Forestry Dept. Virginia Polytechnic Institute and State University Blacksburg, VA

Bolisetty, S. and R. Mezzenga. 2016. Amyloid-carbon hybrid membranes for universal water purification. Nat Nano 11: 365-371. https://doi.org/10.1038/nnano.2015.310

Clean Water Act (CWA), 1972, 33 U.S.C. $§ 1251$ et seq. 
Cormier S, G, Suter, L, Yuan, and L. Zheng (2011) A field-based aquatic life benchmark for conductivity in central appalachian streams. US EPA/600/R-10-023F, National Ctr for Environmental Assessment, Cincinnati, OH, USA.

Daniels, W.L., C.E. Zipper, Z.W. Orndorff, J. Skousen, C.D. Barton, L.M. McDonald, and M.A. Beck. 2016. Predicting total dissolved solids release from central Appalachian coal mine spoils. Environmental Pollution 216: 371-379. http://dx.doi.org/10.1016/j.envpol.2016.05.044

Diawara, C.K. 2008. Nanofiltration Process Efficiency in Water Desalination. Separation and Purification Reviews 37: 303-325. https://doi.org/10.1080/15422110802228770

Edzwald, J.K. and American Water Works Association. 2011. Water quality \& treatment: a handbook on drinking water. McGraw-Hill, New York.

Gusek, J.J. and K.W. Conroy. 2007. Hybrid treatment systems for very acidic mining influenced water. Journal of The American Society of Mining and Reclamation: 259271. https://doi.org/10.21000/JASMR07010259

Košutić, K., I. Novak, L. Sipos, and B. Kunst. 2004. Removal of sulfates and other inorganics from potable water by nanofiltration membranes of characterized porosity. Separation and Purification Technology 37: 177-185. https://doi.org/10.1016/S1383$\underline{5866(03) 00206-5}$

Merovich, G.T., Jr., J.M. Stiles, J.T. Petty, P.F. Ziemkiewicz, and J.B. Fulton. 2007. Water chemistry-based classification of streams and implications for restoring mined appalachian watersheds. Environmental Toxicology and Chemistry 26: 1361-1369. https://doi.org/10.1897/06-424R.1

Oram, B. 2014. Total Dissolved Solids and Water Quality. Water Research Center, Dallas, PA.

Orndorff, Z., W.L. Daniels, M. Beck, and M. Eick. 2010. Leaching Potentials of Coal Spoil and Refuse: Acid-Base Interactions and Electrical Conductivity. Conference Proceedings of 2010 Annual Meeting of the American Society for Mining and Reclamation, Pittsburgh, PA. pp 736-766 https://doi.org/10.21000/JASMR10010736 
Pinto, P.X., S.R. Al-Abed, D.A. Balz, B.A. Butler, R.B. Landy, and S.J. Smith. 2016. Bench-Scale and Pilot-Scale Treatment Technologies for the Removal of Total Dissolved Solids from Coal Mine Water: A Review. Mine Water and the Environment 35: 94-112. https://doi.org/10.1007/s10230-015-0351-7

Pond, G.J., M.E. Passmore, F.A. Borsuk, L. Reynolds, and C.J. Rose. 2008. Downstream effects of mountaintop coal mining: comparing biological conditions using family- and genus-level macroinvertebrate bioassessment tools. Journal of the North American Benthological Society 27: 717-737. https://doi.org/10.1899/08-015.1

Ricci, B.C., C.D. Ferreira, A.O. Aguiar, and M.C.S. Amaral. 2015. Integration of nanofiltration and reverse osmosis for metal separation and sulfuric acid recovery from gold mining effluent. Separation and Purification Technology 154: 11-21. https://doi.org/10.1016/j.seppur.2015.08.040

Rice, E.W., R.B. Baird, A.D. Eaton, and L.S. Clesceri. 2012. Standard methods for the examination of water and wastewater. American Public Health Association, American Water Works Association, and Water Environment Federation.

Rieger, A., P. Steinberger, W. Pelz, R. Haseneder, and G. Härtel. 2009. Mine water treatment by membrane filtration processes -- Experimental investigations on applicability. Desalination \& Water Treatment 6: 54-60. https://doi.org/10.5004/dwt.2009.644

Sierra, C., J.R. Álvarez Saiz, and J.L.R. Gallego. 2013. Nanofiltration of Acid Mine Drainage in an Abandoned Mercury Mining Area. Water, Air, \& Soil Pollution 224: 112. https://doi.org/10.1007/s11270-013-1734-7

Skousen, J. and P. Ziemkiewicz. 2005. Performance of 116 passive treatment systems for acid mine drainage. Conference Proceedings of 2005 National Meeting of the American Society of Mining and Reclamation. Breckenridge, CO. pp 1100-1133 https://doi.org/10.21000/JASMR05011100 
Skousen, J., C.E. Zipper, A. Rose, P.F. Ziemkiewicz, R. Nairn, L.M. McDonald, and R.L. Kleinmann. 2016. Review of Passive Systems for Acid Mine Drainage Treatment. Mine Water and the Environment 36: 133-153. https://doi.org/10.1007/s10230-016$\underline{0417-1}$

Sterlitech. 2016. Flat Sheet Membrane Specifications. Sterlitech Corporation, Kent, WA.

Surface Mining Control and Reclamation Act of 1977 (SMCRA), 30 U.S.C. $§ 1201$ - 1328.

Timpano, A.J., S.H. Schoenholtz, C.E. Zipper, and D.J. Soucek. 2010. Isolating effects of total dissolved solids on aquatic life in central Appalachian coalfield streams. National Meeting of the American Society of Mining and Reclamation, Pittsburgh, PA. pp 1284-1302 https://doi.org/10.21000/JASMR10011284

Visser, T.J.K., S.J. Modise, H.M. Krieg, and K. Keizer. 2001. The removal of acid sulphate pollution by nanofiltration. Desalination 140: 79-86. https://doi.org/10.1016/S0011$\underline{9164(01) 00356-3}$

Ziemkiewicz, P.F., J.G. Skousen, and J. Simmons. 2003. Long-term performance of passive acid mine drainage treatment systems. Mine Water and the Environment 22: 118-129. https://doi.org/10.1007/s10230-003-0012-0 